\title{
Appearance of Some Black Rice Genotype (Oryza Sativa L.) In Two Type of Agroecosystems in the Dried Land of Central Lombok District
}

\author{
L. Sofian; I Gusti Putu Muliarta Aryana; Kisman
}

Dry Land Resource Management Study Program, Postgraduate University of Mataram, Indonesia

http://dx.doi.org/10.18415/ijmmu.v6i5.1152

\begin{abstract}
The purpose of this study was to determine the appearance of black rice rice genotypes and their adaptation to two types of agroecosystems on dry land. The experiment used a randomized block design at each location with 3 replications and at each test 14 experimental plots were arranged. The treatment used 14 genotypes of black rice, namely: 2 elders (Situ Patenggang superior varieties and Baas Selem cultivars), and 12 lines of hope. Parameters observed were flowering age, plant height, number of productive and unproductive tillers per clump, leaf area, panicle length, number of filled grains and empty grains per panicle, weight of 100 grains, grain weight of each clump and grain yield. The results showed that there was no interaction between location and genotype on flowering age, plant height, number of productive tillers and unproductive tillers, panicle length, leaf area, number of filled grains per panicle, weight of 100 grains, grain weight per clump and grain yield, but interacts with the number of empty grains per panicle. The adaptation and stabilization test results showed that genotype G1 which was classified as stable which had general adaptation, and genotype classified as special adapted and very sensitive to environmental changes was G2; G3; G5; G6; G7; G8; G9; G10; G11; G13; and G14, whereas genotypes G4 and G12 are classified as special adaptation in marginal environments.
\end{abstract}

Keywords: Location ; Genotype of Black Rice; Central Lombok District

\section{Introduction}

Dry land agroecosystem is defined as an area or agricultural area whose farming is based on dry land commodities which in this case are commodities other than lowland rice. Second, dry land agroecosystem is defined as a dry climate region whose economic base is agriculture. Third, it is interpreted as an agricultural area in the upstream region of an upland agriculture. One alternative option that is expected to increase crop production potential in order to meet food needs is the use of dry land. Apart from the fact that it is quite widely available, some of the dry land has not been optimally cultivated to allow opportunities for development. Dry land as an agroecosystem that has great potential for agricultural businesses, both food crops, horticulture (vegetables and fruits) as well as annual crops and livestock (Henny Mayrowani et al., 2010; Minardi, 2009; Abdurachman et al., 2008). 
Dry land can be divided into two groups, namely lowland dry land which is at an altitude between 0-700 meters above sea level (masl) and highland dry land that is at an altitude above 700 meters above sea level (masl). Dry land with dry climate is characterized by low rainfall of $1.000-1.500 \mathrm{~mm} /$ year for 3-4 months with irregular distribution. Fluctuations in rainfall are very high, at one time it could reach $100 \mathrm{~mm} /$ day or could stop altogether for 2-3 weeks (Nasiu, 2012). The problem in dry land is the limited groundwater that is able to meet the needs of plants. This can lead to inhibition of plant growth (Theresia M. Sihombing, 2017).

Rice plants grow in very diverse environmental conditions, so it is sometimes difficult to determine the most suitable for their development. However, rice plants have special features, which have wider adaptability and can be cultivated in almost all major land agro-ecosystems, namely wetland, both irrigated and rain-fed (Kasno et al., 2016). Rice plantations are generally dominated by many shortseeded varieties, both in the lowlands $(0-200 \mathrm{~m}$ asl) and in the middlelands $(200-500 \mathrm{~m}$ asl). In the highlands (500-700 m asl), the proportions of the two types of rice varieties are almost comparable (Nuryanto et al., 2014). The development of dryland rice, especially diverse upland rice, is a capital for breeders to assemble and obtain drought tolerant superior varieties (Meutia et al., 2010). Conditions that are not always stable, resulting in a decrease in rice productivity. Handayani et al. (2013) stated this was due to the deteriorating influence of the local environment, as well as the shifting of paddy fields to nonpaddy fields.

Black rice in Indonesia is one of the germplasm which is increasingly rare due to the planting of new superior rice varieties and has a low yield ( 2 tons / ha). Considering this, new superior varieties of black rice need to be assembled that are able to provide high yields and are able to adapt to unfavorable climate change that is able to adapt to drought environments. With the formation of this variety, it will surely be able to maintain sustainable food self-sufficiency, increase food deversification and increase the use of dry land (Muliarta, 2016).

Varieties are one of the important components that contribute to increasing rice production and productivity. The number of superior varieties released can be used as an alternative choice for farmers to choose varieties that are suitable for their agro-climate conditions (Minarsih et al., 2013). Riana Ningsih and Dwi (2017) stated that various efforts had been made to increase national rice production, one of which was the use of improved varieties from breeding. The use of improved varieties is one of the important factors that influence agricultural production and plays a strategic role in supporting the success of Indonesian agriculture. The use of improved varieties will guarantee an increase in the quality of the crop which can improve the welfare of farmers and help government programs in rice self-sufficiency. Improvement of drought tolerant and high yield rice black rice varieties in Indonesia has not received serious attention. At present dryland farmers still use local varieties of deep age and low yield, around 2 tons ha-1 (Muliarta et al., 2017).

The appearance of genotypes for quantitative traits, such as yield components and yield potential, often changes from one environment to another due to mutual action between genotypes and the environment. The relative differences in genotypic responses to the environment often follow a regression pattern. Therefore, it is necessary to examine the possibility of obtaining varieties that have special or broad adaptability and have high yield stability, namely by testing a number of lines of hope or variety at various locations (Muliarta, 2008).

Availability Information regarding interactions between genotypes and the environment and yield stability will give an indication whether the line in question is specific or broad adapted. This information is important for the release and promotion of the use of varieties for commercial purposes (Fikere et al., 2009). The purpose of this study was to determine the appearance of black rice rice genotypes and their adaptation to two types of agroecosystems on dry land. 


\section{Materials and Methods}

The study was conducted from April 2019 to August 2019 which was conducted on two types of agroecosystems on dry land in the Central Lombok District of West Nusa Tenggara Province, namely in Gerantung Village, Praya Tengah District at an altitude of 129 meters above sea level (masl) and in Mantang Village Batukliang District with an altitude of 372 meters above sea level (masl).

The materials used in this study were 14 black rice rice genotypes, namely: 2 elders $(\mathrm{G} 1=$ superior varieties of Situ Patenggang and G2 = Baas Selem cultivars), and 12 hope lines of black rice, namely: G3 = hope strain F9 2/1/1 1/4/2 / P1; G4 = hope line F9 2/1/2/2/2 / P1; G5 = hope line F9 2/1/2/9/2 / P1; G6 = hope line F9 3/1/10/11 / P2; G7 = expectation line F9 3/1/2/7/1 / P1, G8 = expectation line F9 2/3/1/5 / P1; G9 = F9 hope line 1/4/5/1 / P1; G10 = F9 hope line 1/4/6/2 / P1; G11 = hope line F9 1/4/7/1 / P1; G12 = hope line F9 1/4/7/3 / P1; G13 = hope line F9 3/4/2/5/1 / P1; and G14 = hope line F9 3/4/1/3/1 / P1.

The method used in this study was an experimental method arranged using a Randomized Block Design (RBD) at each study site with 3 (three) replications, and at each test 14 plots were arranged. Tillage is done by removing weeds, plowing the soil with plowed, and forming plots. Each plot measures $2.5 \mathrm{~m} \mathrm{x} 7 \mathrm{~m}$ and the distance between plots is $50 \mathrm{~cm}$ on each test, while the distance between tests is 100 $\mathrm{cm}$. Spacing used is $25 \mathrm{~cm} \times 25 \mathrm{~cm}$. Planting is carried out in Portugal with 2 seeds per hole with a depth of planting hole of approximately $3 \mathrm{~cm}$. Basic fertilization is carried out with NPK Phonska fertilizer at the age of 7 days after planting (HST) at a dose of $300 \mathrm{~kg} / \mathrm{ha}$. Furthermore, aftershock fertilization is carried out with Urea, ie the first aftershock is given when the plant is 30 days after planting and the second aftershock is given when the plant is 50 days after the plant with a dose of $100 \mathrm{~kg} / \mathrm{ha}$.

Data collection was carried out by measuring the quantitative nature of each plant that became the study sample. Data collection was carried out by taking a sample of 10 plants per treatment on each test carried out systematically randomly. Parameters observed were flowering age (hst), plant height $(\mathrm{cm})$, number of productive tillers per clump (stem), number of unproductive tillers per clump (stem), leaf area $(\mathrm{cm})$, panicle length $(\mathrm{cm})$, number of filled grains per panicle (grains), the number of empty grains per panicle (grains), the weight of 100 grains (grams), the grain weight per clump (grams) and grain yield (kg / ha).

Data from observations were analyzed by variance (ANOVA) at 5\% level, differences between genotypes were tested by Duncan at $5 \%$ level, followed by analysis of combined variance. Genotype and location (G x L) interactions were evident, followed by Finlay and Wilkinson's (1963) stability analysis. Computing analysis of stability and adaptability using the IBM SPSS Statistics program.

\section{Results and Discussion}

Based on the results of the analysis of variance (ANOVA) combined that there is an interaction between location and genotype. This shows the existence of different responses from genotypes tested at each study location. For more details can be seen in table 1 below. 
Table 1. Results of a mixed analysis (ANOVA) of the parameters observed in the two types of agroecosystems on dry land.

\begin{tabular}{|c|c|c|}
\hline Parameter & Effect & F-Count \\
\hline \multirow{3}{*}{ Flowering age (hst) } & Genotipe & $12.376 * *$ \\
\hline & Location & $155.350 * *$ \\
\hline & Genotipe x Location & $1.480^{\mathrm{ns}}$ \\
\hline \multirow{3}{*}{ Plant height (cm) } & Genotipe & $3.321 * *$ \\
\hline & Location & $5.180 *$ \\
\hline & Genotipe $\mathrm{x}$ Location & $1.542^{\mathrm{ns}}$ \\
\hline \multirow{3}{*}{ Number of productive tillers per family (stems) } & Genotipe & $1.225^{\mathrm{ns}}$ \\
\hline & Location & $1.511^{\mathrm{ns}}$ \\
\hline & Genotipe x Location & $1.799^{\mathrm{ns}}$ \\
\hline \multirow{3}{*}{ Number of unproductive tillers per family (stems) } & Genotipe & $2.305 *$ \\
\hline & Location & $76.097 * *$ \\
\hline & Genotipe $\mathrm{x}$ Location & $1.211^{\mathrm{ns}}$ \\
\hline \multirow{3}{*}{ Panicle length $(\mathrm{cm})$} & Genotipe & $2.865 *$ \\
\hline & Location & $0.038^{\text {ns }}$ \\
\hline & Genotipe $\mathrm{x}$ Location & $1.238^{\mathrm{ns}}$ \\
\hline \multirow{3}{*}{ Leaf area $(\mathrm{cm})$} & Genotipe & $2.734 * *$ \\
\hline & Location & $264.891 * *$ \\
\hline & Genotipe x Location & $1.535^{\mathrm{ns}}$ \\
\hline \multirow{3}{*}{ The number of filled grains per panicle (butir) } & Genotipe & $2.345 * *$ \\
\hline & Location & $1.468^{\mathrm{ns}}$ \\
\hline & Genotipe $\mathrm{x}$ Location & $1.270^{\mathrm{ns}}$ \\
\hline \multirow[b]{3}{*}{ The number of empty grains per panicle (butir) } & Genotipe & $5.989 * *$ \\
\hline & Location & $15.838 * *$ \\
\hline & Genotipe x Location & $2.127 *$ \\
\hline \multirow{3}{*}{ Weight of 100 grains (gram) } & Genotipe & $2.793 * *$ \\
\hline & Lokasi & $2.977^{\mathrm{ns}}$ \\
\hline & Genotipe $\mathrm{x}$ Location & $1.248^{\mathrm{ns}}$ \\
\hline \multirow{3}{*}{ The weight of the grain per clump (gram) } & Genotipe & $0.884^{\mathrm{ns}}$ \\
\hline & Location & $12.911 * *$ \\
\hline & Genotipe $\mathrm{x}$ Location & $1.680^{\mathrm{ns}}$ \\
\hline \multirow{3}{*}{ Grain yield (kg/ha) } & Genotipe & $0.972^{\mathrm{ns}}$ \\
\hline & Location & $61.348 * *$ \\
\hline & Genotipe $\mathrm{x}$ Location & $0.776^{\mathrm{ns}}$ \\
\hline
\end{tabular}

$*=$ real; $* *$ = very real; ns $=$ not real

Table 1 shows that the interaction of genotype and location had no significant effect on flowering age, plant height, number of productive tillers, number of unproductive tillers, panicle length, leaf area, number of filled grains per panicle, and weight of 100 grains, grain weight per clumps and grain yields. And have a significant effect on the number of empty grains per panicle. According to Trustinah and Rudi Iswanto (2013) that genotype $\mathrm{x}$ environment interaction is a common phenomenon that causes differences in the ranking of genotypes in various locations. The results of the analysis of variance showed that the genotype had a very real and not significant effect on the various parameters observed and the location had a very real and no real effect on the various parameters observed. The results of further tests of the influence of location and genotype can be seen in table 2 and table 3. 


\begin{tabular}{|c|c|c|c|c|c|c|c|c|c|c|}
\hline \multirow[b]{2}{*}{ Genotipe } & \multicolumn{10}{|c|}{ Parameter } \\
\hline & $\begin{array}{l}\text { Flowering } \\
\text { Age } \\
\text { (hst) }\end{array}$ & $\begin{array}{l}\text { Plant } \\
\text { height } \\
(\mathrm{cm})\end{array}$ & $\begin{array}{l}\text { Number of } \\
\text { Productive Puppies } \\
\text { per clump } \\
\text { (stem) }\end{array}$ & $\begin{array}{l}\text { Number of } \\
\text { Non-Productive } \\
\text { Puppies per } \\
\text { Clump (stems) }\end{array}$ & $\begin{array}{l}\text { Panicle } \\
\text { length } \\
(\mathrm{cm})\end{array}$ & Leaf Area $(\mathrm{cm})$ & $\begin{array}{l}\text { Amount } \\
\text { of Grain } \\
\text { Containing } \\
\text { per Panicle } \\
\text { (item) }\end{array}$ & $\begin{array}{l}\text { Weight of } \\
100 \text { Grain } \\
\text { (gram) }\end{array}$ & $\begin{array}{l}\text { Grain } \\
\text { Weight } \\
\text { of Each } \\
\text { Clump } \\
\text { (gram) }\end{array}$ & $\begin{array}{l}\text { Grain Results } \\
(\mathrm{kg} / \mathrm{ha})\end{array}$ \\
\hline G1 & $76,83^{a}$ & $103,06^{\text {bcd }}$ & 17,52 & $1,30^{d}$ & $23,65^{\mathrm{de}}$ & $67,60^{\mathrm{c}}$ & $149,10^{\mathrm{bcd}}$ & $2,41^{\text {bcde }}$ & 68,84 & 1,87 \\
\hline $\mathrm{G} 2$ & $91,00^{\mathrm{b}}$ & $102,65^{\text {bcd }}$ & 20,95 & $0,43^{\mathrm{a}}$ & $22,69^{\mathrm{abcd}}$ & $60,69^{\mathrm{bc}}$ & $145,64^{\text {abcd }}$ & $2,32^{\mathrm{a}}$ & 75,23 & 2,19 \\
\hline G3 & $93,17^{\mathrm{b}}$ & $106,85^{\mathrm{cd}}$ & 19,78 & $0,75^{\mathrm{abcd}}$ & $22,59^{\mathrm{abc}}$ & $65,40^{\mathrm{bc}}$ & $146,95^{\text {abcd }}$ & $2,43^{\text {cde }}$ & 72,61 & 2,23 \\
\hline G4 & $93,00^{\mathrm{b}}$ & $105,8^{\mathrm{cd}}$ & 19,4 & $0,93^{\mathrm{abcd}}$ & $23,84^{\mathrm{e}}$ & $65,29^{\mathrm{bc}}$ & $151,36^{\mathrm{cd}}$ & $2,40^{\text {bcde }}$ & 73,17 & 1,52 \\
\hline G5 & $91,50^{\mathrm{b}}$ & $102,63^{\mathrm{bcd}}$ & 19,38 & $0,72^{\mathrm{abcd}}$ & $23,10^{\text {abcde }}$ & $63,31^{b c}$ & $147,54^{\mathrm{abcd}}$ & $2,45^{\mathrm{de}}$ & 73,19 & 2,06 \\
\hline G6 & $91,33^{\mathrm{b}}$ & $109,22^{\mathrm{d}}$ & 19,90 & $1,23^{\mathrm{cd}}$ & $22,75^{\mathrm{abcd}}$ & $66,75^{b c}$ & $144,76^{\mathrm{abcd}}$ & $2,47^{\mathrm{e}}$ & 74,65 & 2,73 \\
\hline G7 & $90,00^{\mathrm{b}}$ & $105,79^{\mathrm{cd}}$ & 20,25 & $0,68^{\mathrm{abc}}$ & $22,15^{\mathrm{a}}$ & $65,71^{b c}$ & $140,59^{\mathrm{ab}}$ & $2,40^{\text {bcde }}$ & 74,60 & 2,50 \\
\hline G8 & $91,83^{\mathrm{b}}$ & $94,17^{\mathrm{a}}$ & 19,57 & $0,70^{\mathrm{abc}}$ & $22,44^{\mathrm{a}}$ & $52,61^{\text {a }}$ & $139,31^{\mathrm{a}}$ & $2,38^{\text {abcd }}$ & 71,03 & 2,64 \\
\hline G9 & $93,33^{\mathrm{b}}$ & $104,55^{\text {bcd }}$ & 19,80 & $0,53^{\mathrm{ab}}$ & $22,78^{\text {abcd }}$ & $64,76^{\mathrm{bc}}$ & $144,40^{\text {abcd }}$ & $2,34^{\mathrm{ab}}$ & 74,10 & 2,25 \\
\hline G10 & $93,50^{\mathrm{b}}$ & $102,83^{\text {bcd }}$ & 20,18 & $1,10^{\mathrm{bcd}}$ & $23,51^{\text {bcde }}$ & $59,34^{\text {ab }}$ & $149,32^{\text {bcd }}$ & $2,37^{\mathrm{abc}}$ & 74,76 & 2,21 \\
\hline G11 & $90,67^{\mathrm{b}}$ & $105,30^{\mathrm{cd}}$ & 18,98 & $0,63^{\mathrm{ab}}$ & $22,58^{\mathrm{abc}}$ & $66,73^{b c}$ & $141,15^{\mathrm{ab}}$ & $2,39^{\text {abcde }}$ & 72,27 & 2,17 \\
\hline G12 & $90,00^{\mathrm{b}}$ & $105,87^{\mathrm{cd}}$ & 18,65 & $0,45^{\mathrm{a}}$ & $22,50^{\mathrm{ab}}$ & $65,79^{b c}$ & $142,73^{\mathrm{abc}}$ & $2,41^{\text {bcde }}$ & 70,78 & 1,79 \\
\hline G13 & $91,67^{\mathrm{b}}$ & $100,85^{\mathrm{bc}}$ & 19,85 & $0,78^{\text {abcd }}$ & $22,49^{\mathrm{ab}}$ & $63,61^{b c}$ & $144,14^{\text {abcd }}$ & $2,42^{\text {cde }}$ & 73,12 & 2,42 \\
\hline G14 & $89,50^{b}$ & $98,36^{\mathrm{ab}}$ & 18,23 & $0,97^{\text {abcd }}$ & $23,59^{\text {cde }}$ & $66,17^{\mathrm{bc}}$ & $152,38^{\mathrm{d}}$ & $2,38^{\text {abcd }}$ & 71,09 & 2,19 \\
\hline
\end{tabular}

Table 2. Average parameters of black rice rice genotypes in two types of agroecosystems in dry land (altitude 129 masl and 372 masl height)

The number accompanied by the same letter in one column shows no significant difference in Duncan's test level $p=0.05$

\begin{tabular}{|c|c|c|c|c|c|c|c|c|c|c|}
\hline \multirow[b]{2}{*}{ Lokasi } & \multicolumn{10}{|c|}{ Parameter } \\
\hline & $\begin{array}{c}\text { Flowering Age } \\
\text { (hst) }\end{array}$ & $\begin{array}{l}\text { Plant height } \\
(\mathrm{cm})\end{array}$ & $\begin{array}{l}\text { Number } \\
\text { of } \\
\text { Productive } \\
\text { Puppies } \\
\text { per clump } \\
\text { (stem) }\end{array}$ & $\begin{array}{c}\text { Number } \\
\text { of Non- } \\
\text { Productive } \\
\text { Puppies } \\
\text { per Clump } \\
\text { (stems) } \\
\end{array}$ & $\begin{array}{c}\text { Panicle } \\
\text { length } \\
(\mathrm{cm})\end{array}$ & $\begin{array}{l}\text { Leaf } \\
\text { Area } \\
(\mathrm{cm})\end{array}$ & $\begin{array}{c}\text { Amount of } \\
\text { Grain } \\
\text { Containing per } \\
\text { Panicle (item) }\end{array}$ & $\begin{array}{l}\text { Weight } \\
\text { of } 100 \\
\text { Grain } \\
\text { (gram) }\end{array}$ & $\begin{array}{l}\text { Grain Weight of } \\
\text { Each Clump } \\
\text { (gram) }\end{array}$ & $\begin{array}{l}\text { Grain Results } \\
\quad(\mathrm{kg} / \mathrm{ha})\end{array}$ \\
\hline $\begin{array}{l}\text { Altitude } 129 \\
\text { meters above } \\
\text { sea level }\end{array}$ & $86,60^{a}$ & $104,69^{a}$ & 19,20 & $1,22^{b}$ & 22,92 & $74,30^{a}$ & 146,51 & 2,41 & $70,92^{b}$ & $2,68^{b}$ \\
\hline $\begin{array}{l}\text { Altitude } 372 \\
\text { meters above } \\
\text { sea level }\end{array}$ & $94,48^{b}$ & $102,13^{b}$ & 19,71 & $0,37^{a}$ & 22,86 & $53,35^{\mathrm{b}}$ & 144,61 & 2,39 & $74,69^{a}$ & $4,39^{\mathrm{a}}$ \\
\hline
\end{tabular}

The number accompanied by the same letter in one column shows no significant difference in Duncan's test level $p=0.05$ 
Table 2 shows that the G1 genotype as an elder has a fast flowering age and is significantly different from other genotypes including the G2 genotype which is also an elder. This shows that the G1 genotype has genetic traits that more quickly adapt to location so that it greatly influences flowering age. The difference in flowering age in each genotype is thought to be caused by the length of the vegetative phase of each genotype. Makarim and Suhartatik (2009) revealed that the longer the flowering period, the longer the harvest period. The length of the flowering phase for most varieties in the tropics is generally 35 days and the maturation phase is 30 days). In plant height parameters, where the G6 genotype has a tall stem but is not significantly different from the 2 elders and other genotypes, but it is significantly different from the genotypes G8 and G14 which have short stems. The height of the stem of the plant is thought to be the adaptive nature found in the plant. Anhar et al. (2016) stated that the number of tillers and plant height were different because each variety had different gene traits. Nazirah and Damanik (2015) stated that differences in genetic makeup are one of the factors that cause diverse plant appearance in this case is plant height. Plants that have high stems are not guaranteed to have high productivity as well because the higher the stems, the easier the plants will experience lodging so that the fruit production process will be disrupted and the resulting crop will also be reduced. This is in line with the statement of Aribawa (2012) that high plant growth does not guarantee high plant productivity.

The results of further tests on the number of unproductive tillers, showed that the genotype G2 parents had a small number of unproductive tillers and were not significantly different from other genotypes, but significantly different from the G1 genotype which is also an elder who has a large number of unproductive tillers (table 2). The difference in the number of unproductive tillers in each genotype has the ability to form the number of productive tillers which are influenced by genetic factors contained in each genotype. The results of further trials on panicle lengths, the results obtained that the genotype G4 has the longest panicle and not significantly different from the parents of genotype G1 but significantly different from the parents of genotype G2 which has shorter panicle lengths (table 2). The panicle length will affect the number of results so that each panicle length increases, it will produce more grain. According to Utama and Haryoko (2009) that panicle length is one of the important parameters determining the level of productivity of a strain / variety because the longer panicle, the more rice grain there is and most likely the filled grain / rice grain will be higher. Furthermore Dewi et al. (2009) states that panicle length usually has a correlation with the number of grains per panicle. According to Adie (2008) the results of rice production are highly dependent on the length of panicles that grow on productive tillers, this is because panicles are where the rice grains are attached. In general, the longer the rice panicle, the more rice grains will be produced. Panicle length also has a positive correlation with plant height.

The results of further tests on leaf area showed that the parents of genotype G1 had broad leaves but were not significantly different from the parents of genotype G2 and other genotypes, but were significantly different from genotypes G8 and G10 which had narrow leaves (table 2). In the growth and development of plants, the leaves are the main organ of rice plants to carry out the process of photosynthesis so that with the increasing breadth of the leaves the more light that can be captured by plants so that the process of photosynthesis will be higher. This is according to Kisman et al. (2007) that the increase in leaf area aims to increase the efficiency of light absorption, so that the process of photosynthesis can run normally. According to Guswanto (2009) that a high net assimilation rate and optimum leaf area index increase plant growth. The results of further tests on the number of filled grains per panicle, where the G14 genotype had a large number of filled grains per panicle and were not significantly different from the two elders and other genotypes but were very significantly different from the G8 genotype which had a small number of filled grains per panicle (table 2 ). The number of filled grains per panicle will determine the productivity of black rice. If the panicles formed produce a lot of filled grain, the productivity of black rice is high. Abdullah et al. (2008), said that new types of rice with high yield potential generally must have good characteristics including the number of grains per panicle 150-250 grains. According to Lestari and Nugraha (2007) that the amount of grain per panicle is 
positively correlated with production, meaning that the more the number of grain per panicle, the higher the chance of the variety in producing production as long as the number of empty grains is not high. to the weight of 100 grains, it is known that the G6 genotype has the heaviest weight and is not significantly different from the parents of the G1 genotype but is significantly different from the other parents namely the G2 genotype which has a light weight (table 2). The weight of a grain indicates that the filling process is complete. The physical characteristics of grain in several black rice genotypes differ in quality and appearance because they are influenced by the water content in the grain itself. According to Rahimi et al. (2012) that differences in grain weight occur due to differences in size and shape of rice grains, in the same variety will produce the shape and size of rice grains that are relatively similar, because differences in character in rice grains are determined by genetic factors owned by rice.

Table 3 shows that the flowering age parameters, where a location with a height of 129 meters above sea level resulted in a faster flowering age for black rice genotypes (table 3). Age of flowering is greatly influenced by environmental factors, a suitable environment will increase the flowering process or the release of black rice plant panicles. The most influential environmental factor for flowering age is temperature. Temperature will accelerate the flowering process of black rice. At locations with an altitude of 129 masl have temperatures ranging between $25^{\circ} \mathrm{C}-31^{\circ} \mathrm{C}$, while at locations with an altitude of 372 masl have temperatures ranging from $20^{\circ} \mathrm{C}$ in July 2019. According to Isoda et al. (2010) that temperatures that are too high in the reproductive phase result in a decrease in crop yield. Based on the results of a variety of plant height analysis, that at locations with a height of 129 meters above sea level produces higher plants than at a location with a height of 372 meters above sea level (table 3). Nutrient and water content in the soil influence the increase in plant height. Based on the results of soil analysis conducted, where the NPK content in locations with a height of 129 meters above sea level is N $(0.06 \%)$; $\mathrm{P}(102.04 \mathrm{ppm})$; and $\mathrm{K}$ (1.31 meq\%), while in locations with an altitude of 372 meters above sea level are N (0.04\%); P (160.20 ppm); and K (1.36 meq\%). Lakitan (2008) states that the amount of nutrients needed by plants is closely related to the needs of plants to grow better, if the amount of nutrients is not available then growth will be hampered, but if the amount of nutrients available is higher than the number of elements needed nutrients by plants can be said to be a condition of luxury consumption. A plant is said to be deficient (deficient) of certain nutrients if growth is stunted, ie only $80 \%$ of maximum growth. According to Santoso (2010), there are several parameters that can be seen if plants need water, including plant height. Plants that experience a shortage of water growth needs are stunted so that plants become stunted. Optimal environmental conditions can provide maximum plant growth. One of the abiotic environments that influence the physiological processes of plants is rainfall. Based on data from the West Lombok Climatology Station (2019), that rainfall in April 2019 at a location with an altitude of 129 meters above sea level is $235 \mathrm{~mm}$, while at a location with an altitude of 372 meters above sea level is 246 with the same number of rainy days which is 11-12 days. In both locations where rainfall in June-July 2019 ranges from 21-50 mm, and in August 2019 ranges from 0-20 mm.

In the number of nonproductive tillers, where the location with an altitude of 372 meters above sea level results in a number of unproductive tillers that are less than the location with an altitude of 129 meters above sea level (table 3). This is due to the fact that at higher locations it has good humidity which encourages the black rice seedlings to be productive. According to Thamrin et al. (2011) that the more non-productive tillers will cause a more humid microenvironment. The leaf area parameter shows that the location with a height of 129 meters above sea level gives an influence on the increase in leaf area of black rice genotype (table 3 ). This is supported by the high nitrogen $(\mathrm{N})$ content at locations with an altitude of 129 masl which is $0.06 \%$, where nitrogen $(\mathrm{N})$ is needed by plants for the formation or growth of vegetative parts of plants such as leaves. According to Guswanto (2009) that a high net assimilation rate and optimum leaf area index increase plant growth. The grain weight of each clump shows that the location with an altitude of 372 masl produces grain weight per heavy black rice genotype family (table 3 ). The weight of the grain is determined by the grain's water content. Results of research by Muliarta et al. (2017) showed that the G1 strain (F9 2/1/1) had a relatively high yield of 6.53 tons ha-1 with the grain 
weight characteristics per clump (55.68 grams); and G7 strain (F9 3/4/1) with a yield of 6.35 tons ha-1 with grain weight per clump (50.47 grams). In the grain yield parameters it is known that the black rice rice genotype has high grain yields at locations with an altitude of 372 masl (table 3 ). This shows that the higher location has good humidity, temperature, and light reception thus increasing the generative growth process of black rice. In addition, the location with an altitude of 372 meters above sea level has a high phosphate nutrient $(\mathrm{P})$ content of $160.20 \mathrm{ppm}$. Where the element phosphate $(\mathrm{P})$ plays a role in the process of respiration and photosynthesis, the preparation of nucleic acids, the formation of plant seeds and fruit producers, stimulating root development, so that plants will be more resistant to drought, and speed up the harvest so that it can reduce the risk of delay in harvest time. Changes in the character of the results of a stable genotype will not be affected by the environment, the study of Dewi et al. (2015) showed that DH mutants could still produce high even though the environmental index for character yields was high. DH strains in previous studies were also indicated to be stable and have a special adaptability to drought-strained environments (Muliarta, 2009).

The results of the analysis of variance showed that the interaction of genotype $\mathrm{x}$ location had a significant effect on the number of empty grains per panicle. For more details can be seen in table 4 below.

Table 4. Results of various analyzes of genotype and location interactions on the number of empty grains per panicle in two types of agroecosystems on dry land

\begin{tabular}{|c|c|c|}
\hline \multirow{2}{*}{ Genotipe } & \multicolumn{2}{|c|}{ Location } \\
\hline & Altitude 129 meters above sea level & Altitude 372 meters above sea level \\
\hline $\mathrm{G}_{1}$ & $12.60^{\mathrm{a}}$ & $12.60^{\mathrm{a}}$ \\
\hline $\mathrm{G}_{2}$ & $14.07^{\mathrm{abcd}}$ & $16.25^{\text {defghijk }}$ \\
\hline $\mathrm{G}_{3}$ & $12.77^{\mathrm{ab}}$ & $17.24^{\text {efghijkl }}$ \\
\hline $\mathrm{G}_{4}$ & $16.27^{\text {defghijk }}$ & $16.26^{\text {defghijk }}$ \\
\hline $\mathrm{G}_{5}$ & $14.57^{\text {abcdef }}$ & $17.71^{\mathrm{hijkl}}$ \\
\hline $\mathrm{G}_{6}$ & $14.40^{\text {abcde }}$ & $18.15^{\text {hijkl }}$ \\
\hline $\mathrm{G}_{7}$ & $15.47^{\text {abcde }}$ & $19.33^{\mathrm{hijkl}}$ \\
\hline $\mathrm{G}_{8}$ & $16.73^{\text {defghijkl }}$ & $17.23^{\text {efghijkl }}$ \\
\hline $\mathrm{G}_{9}$ & $17.37^{\text {ghijkl }}$ & $18.10^{\mathrm{hijkl}}$ \\
\hline $\mathrm{G}_{10}$ & $18.23^{\mathrm{ijkl}}$ & $17.63^{\text {hijkl }}$ \\
\hline $\mathrm{G}_{11}$ & $16.43^{\text {defghijk }}$ & $17.53^{\text {hijkl }}$ \\
\hline $\mathrm{G}_{12}$ & $18.70^{\mathrm{kl}}$ & $18.57^{\mathrm{jkl}}$ \\
\hline $\mathrm{G}_{13}$ & $16.90^{\text {defghijkl }}$ & $15.77^{\text {cdefghi }}$ \\
\hline $\mathrm{G}_{14}$ & $13.10^{\mathrm{abc}}$ & $15.27^{\text {abcdefg }}$ \\
\hline
\end{tabular}

The number accompanied by the same letter in one column shows no significant difference in Duncan's test level $p=0.05$

Table 4 shows that genotypes and locations interact significantly with the number of empty grains per panicle in genotypes G3, G5, G6, and G7. The genotype and location of interaction did not significantly affect the number of empty grains per panicle in the two elders (genotypes G1 and G2), as well as genotypes G4, G8, G9, G10, G11, G12, G13, and G14. Muliarta (2012) states that there are differences in the number of empty grains per panicle between lines due to genetic differences between genotypes. According to Limbongan (2008) that the relative order of a variety will change from place to place and from season to season with the interaction of $\mathrm{G} \times \mathrm{E}$. A genotype will be able to grow and produce equally well in various places or growth environments if there is no $\mathrm{G} x$ interaction $\mathrm{E}$ so that the variety or strain can be said to be stable. Stable varieties are very important to reduce the risk due to 
unpredictable environmental changes such as soil fertility, striking weather changes and pest and disease attacks.

Genotypes that can overcome unfavorable environmental conditions will have good adaptation and stability results. Finlay and Wilkinson (1965), suggested that the method of stability analysis is by making a linear regression of the yield of each genotype over the average yield of all genotypes for each location. The results of adaptation and stability test results of black rice rice genotypes can be seen in table 5 below.

Table 5. Adaptation and stability test results of several black rice genotypes on two types of agroecosystems on dry land

\begin{tabular}{cccc}
\hline Genotipe & Grain yield $(\mathbf{K g} / \mathbf{h a})$ & $\begin{array}{c}\text { Regression Coefficient } \\
\text { (bi) }\end{array}$ & $\begin{array}{c}\text { Standard Error } \\
\end{array}$ \\
& & & \\
\hline $\mathrm{G}_{1}$ & 1.870 & 0.910 & 0.826 \\
$\mathrm{G}_{2}$ & 2.194 & 1.780 & 0.987 \\
$\mathrm{G}_{3}$ & 2.229 & 2.509 & 0.761 \\
$\mathrm{G}_{4}$ & 1.520 & 0.664 & 0.627 \\
$\mathrm{G}_{5}$ & 2.061 & 1.784 & 0.985 \\
$\mathrm{G}_{6}$ & 2.734 & 2.549 & 0.301 \\
$\mathrm{G}_{7}$ & 2.505 & 1.903 & 0.886 \\
$\mathrm{G}_{8}$ & 2.639 & 3.103 & 0.635 \\
$\mathrm{G}_{9}$ & 2.249 & 1.896 & 0.494 \\
$\mathrm{G}_{10}$ & 2.208 & 1.633 & 0.835 \\
$\mathrm{G}_{11}$ & 2.175 & 1.811 & 1.035 \\
$\mathrm{G}_{12}$ & 1.791 & 0.465 & 1.205 \\
$\mathrm{G}_{13}$ & 2.418 & 1.349 & 0.574 \\
$\mathrm{G}_{14}$ & 2.190 & 1.716 & 0.879 \\
\hline
\end{tabular}

Table 5 shows that the $\mathrm{G} 1$ genotype has a regression coefficient close to 1.0 indicating an average stability so it has a good general level of adaptation. Genotype G2; G3; G5; G6; G7; G8; G9; G10; G11; G13; and G14 has a regression coefficient above 1.0 indicating stability below the average so it is very sensitive to environmental changes and adapts to special environments, whereas genotypes G4 and G12 have regression coefficients that are getting smaller below 1.0 which indicates stability above average. special adaptation in the marginal environment. Syukur et al. (2015) emphasized that varieties are able to adapt well are varieties consisting of a number of different genotypes. Each genotype has the ability to adapt to different environmental ranges. 


\section{Conclusions and Suggestions}

\section{Kesimpulan}

a. Genotype interactions and real locations occur in the number of empty grains per panicle, indicating the presence of certain genotypes that are suitable for specific environments.

b. There was no interaction between genotype and location on flowering age, plant height, number of productive tillers and unproductive tillers, panicle length, leaf area, number of filled grains per panicle, weight of 100 grains, grain weight of each clump and grain yield.

c. Got genotype which is classified as stable which has general adaptation, and genotype which is classified as special adaptation and is very sensitive to environmental changes is G2; G3; G5; G6; G7; G8; G9; G10; G11; G13; and G14, whereas genotypes G4 and G12 are classified as special adaptation in marginal environments.

\section{Suggestions}

Genotype G6 = F9 expected strain 3/1/10/11 / P2 and Genotype G8 = expected strain F9 2/3/1/5 / P1 to be used as a source of germplasm to be developed into new superior varieties because it is able to adapt and produce high in dry land.

\section{References}

Abdullah,B., S. Tjokrowidodo, dan Sularjo, 2008. Perkembangan dan Prospek Perakitan padi Tipe Baru di Indonesia. Jurnal Litbang Pertanian. 27 :1-9 Anhar, R., H. Erita. dan Efendi. 2016. Pengaruh dosis pupuk urea terhadap pertumbuhan dan produksi plasma nutfah padi lokal asal Aceh. Jurnal Kawista. 1(1): 30-36.

Abdurachman, A., A. Dariah, dan A. Mulyani, 2008. Strategi dan Teknologi Pengelolaan Lahan Kering Mendukung Pengadaan Pangan Nasional. Jurnal Penelitian dan Pengembangan Pertanian 27 (2) 2008: 43-49.

Adie YI., 2008. Produksi dan Produktivitas Tanaman Pertanian Utama di Kabupaten Cianjur Berdasarkan Profil Ketinggian Tempat (Tinjauan pada Empat Ketinggian Tempat). Departemen Geofisika dan Meteorologi Fakultas Matematika dan Ilmu Pengetahuan Alam Institut Pertanian Bogor.

Anhar, R., E. Hayati, dan E. Efendi, 2016. Pengaruh Dosis Pupuk Urea terhadap Pertumbuhan dan Produksi Plasma Nutfah Padi Lokal Asal Aceh. Jurnal Kawista Agroteknologi. 1 (1): 30-36.

Aribawa, 2012. Pengaruh Sistem Tanam terhadap Peningkatan Produktivitas Padi di Lahan Sawah Dataran Tinggi Beriklim Basah. Balai Pengkajian Teknologi Pertanian (BPTP). 
Dewi I. S., Purwoko B.S dan Herawati R., 2009. Keragaman Genetik dan Karakter Agronomi Galur Haploid Ganda Padi Gogo dengan Sifat Tipe Baru Hasil Kultur Antera. J. Agron. Indonesia 37 (2):87-94 (2009).

Fikere, M., E. Fikiru, T. Tadese, and T. Legesse, 2019. Parametric Stability Analysis in Field Pea (Pisum sativum L.) Under South Eastern Ethiopia Condition. Word J. Agric, Sci. 5 (2): 146-151.

Finlay, K.W. and G.N. Wilkinson, 1963. The Analysis of Adaptation in Plant Breeding Program. Aust. J. Res. 13:742-754.

Guswanto, 2009. Teknik Pengukuran Luas Daun. Materi Teknik Pengukuran Luas Daun.

Handayani, A., Sriyanto, dan I. Sulistyawati, 2013. Evaluasi Mutu Beras dan Tingkat Kesesuaian Penanganannya (Studi Khusus di Kabupaten Karang Anyar). Jurnal Litbang Provinsi Jawa Tengah. Vol. 11 No 1: 113 - 124.

Henny Mayrowani, Sumaryanto, Delima Hasri Azhari, Nyak Ilham, Supena Friyatno, dan Ashari, 2010. Optimalisasi Sumber Daya Pertanian pada Agroekosistem Lahan Kering. Pusat Analisis Sosial ekonomi dan Kebijakan Pertanian. Badan Penelitian dan Pengembangan Pertanian, Kementerian. J Pertanian. Makalah Seminar Proposal Operasional T.A. 2010.

Isoda, A., H. Mao, Z. Li and P. Wang, 2010. Growth of High-Yielding Soybeans and its Relation to Air Temperature in Xinjiang, China, Plant Production Sci. 13:2, 209-217.

Kasno, A., Rostaman, T., and Setyorini, D., 2016. Peningkatan Produktivitas Lahan Sawah Tadah Hujan dengan Pemupukan Hara N, P, K dan Penggunaan Padi Varietas Unggul. Jurnal Tanah dan Iklim (Indonesian Soil and Climate Journal), 40 (2), 147- 157.

Kisman, N. Khumaida, Trikoessoemaningtyas, Sobir, dan D. Sopandie, 2007. Karakter Morfofisiologi Daun, Penciri Adaptasi Kedelai terhadap Intensitas Cahaya Rendah. Bul. Agron. 35:96-102.

Lakitan, B., 2008. Dasar-Dasar Fisiologi Tumbuhan. Raja Grafindo Persada, Jakarta. 205 hal.

Limbongan YL, Aswidinnoor H, Purwoko BS dan Trikoesoemaningtyas, 2008. Pewarisan Sifat Toleransi Padi Sawah (Oryza sativaL.) Terhadap Cekaman Suhu Rendah. Bul. Agron. 36(2):111 -117.

Lestari, A.P. dan Y. Nugraha, 2007. Keragaan Genetik Hasil dan Komponen Hasil Galur-Galur padi hasil kultur anter. Jurnal Penelitian Pertanian Tanaman Pangan 25(1): 8-13.

Makarim A. K., E., Suhartatik, 2009. Morfologi dan Fisiologi Tanaman Padi. Di dalam: Suyamto, I Nyoman Widiarta, Satoto (ed.). Padi: Inovasi Teknologi dan Ketahanan Pangan. Buku 1. LIPI Press. Jakarta. 295-330.

Meutia, S.A.; A. Anwar, dan I. Suliansyah, 2010. Uji Toleransi Beberapa Genotipe Padi Lokal (Oryza sativa L.) Sumatera Barat terhadap Cekaman Kekeringan. Jerami. 3(2):71-81.

Minardi, 2009. Optimalisasi Pengelolaan Lahan Kering Untuk Pengembangan Pertanian Tanaman Pangan. Pidato Pengukuhan Guru Besar Ilmu Tanah Pada Fakultas Pertanian Universitas Sebelas Maret. Surakarta. 
Minarsih, A., Prayudi, B., Warsito, 2013. Keragaan Beberapa Varietas Unggul Baru Padi Sawah Irigasi dengan Menerapkan Pengelolaan Tanaman Terpadu (PTT) di Kabupaten Klaten. Seminar Nasional: Menggagas Kebangkitan Komoditas Unggulan Lokal Pertanian dan Kelautan Fakultas Pertanian Universitas Trunojoyo Madura; 2013; Madura, Indonesia. Madura (ID). Balai Pengkajian Teknologi Pertanian Jawa Tengah. hlm 582-587.

Muliarta A, IGP., I Made Sudantha, I Nyoman Soemeinaboedhy, dan Siti Permatasari, 2008. Pengujian Adaptasi dan Ketahanan Hama Penyakit Galur Harapan Beras Merah dalam Rangka Pelepasan Varietas Unggul Spesifik Lokasi. Universitas Mataram.

Muliarta A, IGP., 2009. Adaptasi dan Stabilitas Hasil Galur-Galur Padi Beras Merah pada Tiga Lingkungan Tumbuh. Program Studi Pemuliaan Tanaman, Fakultas Pertanian, Universitas Mataram, NTB, Indonesia.

Muliarta, I.G.P., Sudanta, I.M., Santoso, B.B., 2012. Pengembangan Padi Gogo Beras Merah Potensi Hasil Tinggi dengan Kandungan Antosianin Tinggi. Penelitian Insentif Riset Sinas RT-2012-248 (laporan peneltian). $50 \mathrm{hlm}$.

Muliarta A, IGP., 2016. Perakitan Varietas Unggul Padi Beras Hitam Fungsional Toleran Kekeringan serta Berdaya Hasil Tinggi. Universitas Mataram.

Muliarta A, IGP., AA. Sudharmawan, Sumarjan, dan Dwi Ratna Anugrahwati, 2017. Penampilan Galur Harapan F9 Padi Beras Hitam Hasil Persilangan Baas Selem dan Situ Patenggang.Program Studi Agroekoteknologi Fakultas Pertanian, Universitas Mataram, Indonesia.

Nasiu, F., 2012. Pemanfaatan Lahan Kering Marginal melalui Integrasi Tanaman Pangan, Tanaman Pakan, dan Ternak Ruminansia. Tugas Makalah Budi daya Hijauan Pakan dan Pastura. Program Pascasarjana. Universitas Gajahmada Yogyakarta. (Tidak dipublikasikan).

Nazirah, L. dan B.S.J. Damanik, 2015. Pertumbuhan dan Hasil Tiga Varietas Padi Gogo pada Perlakuan Pemupukan. Jurnal Floratek. 10:54-60.

Nuryanto, A. Priyatmojo, dan B. Hadisutrisno B., 2014. Pengaruh Tinggi Tempat dan Tipe Tanaman Padi terhadap Keparahan Penyakit Hawar Pelepah. Balai Besar Penelitian Pertanian Tanaman Pangan Vol. 33 No. 12014.

Rahimi, Z., E. Zuhry, dan Nurbaiti., 2012. Pengaruh Jarak Tanam terhadap Pertumbuhan dan Produksi Padi Sawah (Oryza sativa L.) Varietas Batang Piaman dengan Metode SRI di Padang Marpoyan Pekanbaru.

Riani Ningsih dan Dwi Rahmawati, 2017. Aplikasi Paclobutrazol dan Pupuk Makro Anorganik terhadap Hasil dan Mutu Benih Padi (Oryza sativa L.). Program Studi Teknik Produksi Benih, Jurusan Produksi Pertanian, Politeknik Negeri Jember. Journal of Applied Agricultural Sciences. Maret, 2017.

Santoso B., 2010. Faktor-faktor Pertumbuhan dan Penggolongan Tanaman Hias. Fakultas Pertanian. Universitas Gajah Mada. Yogyakarta.

Stasiun Klimatologi Lombok Barat, 2019. Buletin Iklim Provinsi Nusa Tenggara Barat. Lombok BaratNusa Tenggara Barat. 
Syukur M., Sujiprihati S., dan Yunianti R., 2015. Teknik Pemuliaan Tanaman. Jakarta (ID) : Penebar Swadaya.

Thamrin, M., 2011. Keberadaan Musuh Alami pada Areal Padi dan Gulma Teki di Lahan Rawa Pasang Surut. 131-138. Dalam Ahmad, I., R.E. Putra, T. Turmuktini, Y. Muliani, Endang, Kantikowati, I. Kinasih, R. Meliansyah dan I.N. Bari (Ed). Prosiding Seminar Nasional Hidup Sejahtera Bersama Serangga. Perhimpunan Entomologi Indonesia Cabang Bandung.

Theresia M. Sihombing, Damanhuri, dan Ainurrasjid, 2017. Uji Ketahanan Tiga Genotip Padi Hitam (Oryza Sativa L.) terhadap Cekaman Kekeringan. Fakultas Pertanian, Universitas Brawijaya. Jurnal Produksi Tanaman Vol. 5 No. 12, Desember 2017: 2026 - 2031.

Trustinah dan Rudi Iswanto, 2013. Pengaruh Interaksi Genotipe x Lingkungan terhadap Hasil Galur Harapan padi Sawah. Balai Besar Penelitian Pertanian Tanaman Pangan Vol. 32 Nomor 12013.

Utama, M. Z. H dan W. Haryoko, 2009. Pengujian Empat Varietas Padi Unggul pada Sawah Gambut Bukaan Baru di Kabupaten Padang Pariaman. Jurnal Akta Agrosia. 12 (1) : 56-61 hal.

\section{Copyrights}

Copyright for this article is retained by the author(s), with first publication rights granted to the journal.

This is an open-access article distributed under the terms and conditions of the Creative Commons Attribution license (http://creativecommons.org/licenses/by/4.0/). 